Www.jmscr.igmpublication.org

Impact Factor (SJIF): 6.379

Index Copernicus Value: 71.58

ISSN (e)-2347-176x ISSN (p) 2455-0450

crossrefDOI: https://dx.doi.org/10.18535/jmscr/v6i7.186

Journal Of Medical Science And Clinical Research

\title{
Medical Negligence: It's Gradual Progression from Ignorance, Ignored and
} Ignominy

\author{
Authors \\ Devendra Singh, LLM, Ph D (Scholar) ${ }^{1}$, Dr Munawwar Husain, MD, DNB, MNAMS ${ }^{2}$, \\ Dr Md Mojahid Anwar, MD ${ }^{3}$, Hena Fatma, MA (Cl Psychology), Ph D (Scholar) ${ }^{4}$ \\ ${ }^{1}$ Civil Judge (JD), Badaun, U.P, India \\ Email:dev13ad@gmail.com \\ ${ }^{2}$ Professor and Chairman, Department of Forensic Medicine \\ Email: husain.uia@gmail.com \\ ${ }^{3}$ Assist Professor, Department of Forensic Medicine \\ Email:dr.mojahidanwar@gmail.com \\ ${ }^{4}$ Research Scholar, Department of Psychology, AMU, Aligarh 202002, India \\ Email: hena.ali01@gmail.com \\ Corresponding Author \\ Professor Munawwar Husain \\ Email: husain.uia@gmail.com, Mobile No.+919997497939
}

\begin{abstract}
The current topic has been chosen for discussion because it is having insalubrious impact on the society. The members of the society have started losing faith in doctors accentuated by their behaviour. The authors have tried to dissect this malady by phrasing it into phases and then applying their mind as to what have greatly contributed towards this malady. To a certain extent the authors have contributed in analysing the problem and offering few suggestions which would help in managing the rot. The discussion follows below.

Keywords: evolution of medical negligence, ignominy, Chanaka Samhita, Sushruta Samhita.
\end{abstract}

\section{Historical Glimpses}

In ancient India the concept of medicine and family welfare was structurally sound and was called science of Ayurveda ${ }^{1}$. The deity associated was Dhanvantri considered an authority on Ayurveda and traditionally carried the stick (danda) and water pot (kamandal) ${ }^{2}$. Rigveda Samhita is the only primary collection detailing the progress of treatment and symptoms covering the period around 700 B.C.

Praiseworthy work on medical science in ancient India could be found in Charak Samhita, Sushruta
Samhita and Vagbhata ${ }^{3}$. Manusmriti moulded measures for safeguarding patients against irresponsible physicians ${ }^{4}$ penalties were imposed by king in case of negligence by the physician according to gravity of lapse and which has been further defined in Yajnavalkya Smriti and Vishnu Smriti

How can a physician be punished and fined for perceived dereliction of duty towards the patient unless the duties of physician are elaborated and made to realize by the physician? This was taken care of in Sushruta Samhita. Physicians (Vaidyas) 
were bound certain restrictions like treating hunters, fowlers outcast and sinners ${ }^{5}$. Kautilyas's Arthashastra is a remarkable example of medico legal ethics to be practised by physicians prior informing the "gopa" or "sthanika" who was the administrative authority vested with disciplinary powers. Arthshastra also deals with liabilities and responsibilities associated with vaidyas.

The framework of punishment has been specified in several literatures. The word "Mithya" was applied in different situations; namely, "wrong treatment" (Charak Samhita), improper conduct or "Mithyopachara". Hierarchical position was considered while imposing punishment on the physician as Yajnavalkya Smriti elaborates initial fine in case of animals, next high in case of man and the highest in case of kings men and nobility" .

It can be realized that specifically medical negligence was not defined under such banner but the society realized that damage done to the patient by the physician could not have taken place unless the physician acted irresponsibly. This could be taken up as the period of enlightenment.

\section{Ancient England}

In this epoch which though gave rise to the origin of medical negligence by laying down the skeletal structure yet fell short of authoritative and confrontational pursuance.

Precursor to modern treatment was laid down under divinity of healing ${ }^{7}$. The fore bearers were the Greeks who modelled different methods of treatment described in myth of Aesulapius ${ }^{8}$. Apollo (god of truth) gave birth to Aesculapius who had healing powers and people would flock to temples and statues erected in honour of Aesculapius for cure? .

Finally it was Hippocrates who carried the torch of modern medicine and honoured for erecting the guidelines and preamble to ethical medical profession bearing the name 'Hippocratic Oath'10. The concept of medical negligence was developed from the English law crafted from the rule "imperitia culpa annumerature" meaning "want of skill is reckoned as fault"11.

In the final shape medical negligence is construed under (i) duty of care (ii) breach of duty to take care and (iii) proximate cause leading to injury.

\section{Modern and Contemporary Phase}

The current phase of ignominy in the ongoing discussion can be dealt with the impact of simultaneous mushrooming of big corporate hospitals dispensing diagnosis and treatment by high end value technology. Earlier the physician provided treatment in very less amount of money. Patient looked upon the physician as saviour and loved one and respected him. It is not-for-nothing that medical profession was an emblem of nobility. With the advent of costly investigations and treatment coupled with do-not-care attitude of physician towards their patients the profession has glided in to the phase of 'IGNOMINY' with no end in sight.

The courts have taken the matter seriously and have imposed consecutively high penalties on the erring doctors. Few such instances are illustrative and eye opener.

\section{Important Medical Negligent Cases in India}

1) Kunal Shah v. AMRI [Advanced Medical research Institute, Kolkata]. After establishing medical negligence leading to the death of the patient the Court imposed compensation of around rupees 6.08 crores $^{12}$.

2) Krishna Rao v. Nikhil Super speciality Hospital [2010]. After examining the case the Court awarded compensation of rupees 2 lakhs based on the principle of "res ipsa loquitor" (the thing speaks for itself) ${ }^{13}$.

3) Aparna Dutt v. Apollo Hospital Enterprises Ltd. The Court recognised negligence based on the principle of "qui facet per alium facit per se", i.e., the principle of vicarious responsibility meaning thereby that one who acts through another act in his or her own interest ${ }^{14}$. 
4) Pravat Kumar Mukherjee v. Ruby General Hospital, Kolkata and Ors. This was annoying case in which an accident victim who happened to be $\mathrm{B}$. Tech student was take to Ruby Hospital, Kolkata, and the hospital demanded Rs 15000/- for starting the treatment. Upon non-payment of this money the hospital discontinued the treatment and the boy was rushed to another hospital. He died on the way. The Court awarded 10 lakhs compensation to the parents of the victim ${ }^{15}$.

\section{Conclusion}

From the above discussion it can be realized that mushrooming of medical negligence cases all over India has given rise to resentment among the general masses. The Courts have also hardened their attitude and this is very well illustrated by the rising level of compensation being awarded to the unfortunate victim of physician's bellicosity. Gone are the days when the physician let forego his or her own comfort for the sake of their patients. The cost of treatment has risen exponentially accentuating the recent phenomenon "defensive medicine" which is nothing but "you scratch my back and I shall scratch yours". The medical profession instead being noble have now become ignominious. It is time the medical fraternity wake up to the call and displays their mettle in professional manner.

\section{References}

1. Chanaka Samhita (3.8)

2. Chanaka Samhita (4.6)

3. Bhishagritna, Kunji Lal: Sushruta Samhita (1-2) ed., Calcutta (1907)

4. Manusmriti, IX 284

5. Sushruta Samhita (1-2)

6. Shastri VL. Yajnavalkyasmriti, $4^{\text {th }}$ ed., Bombay (1936)

7. John Heavly, Medical Negligence: Common Law Perspectives; Sweet \$ Maxwell, London, 1999, p112.
8. KPS Mahalwac; Medical Negligence and the Concept, Liabilities and remedies. Deep and Deep Publishers, New Delhi, 1991, p124.

9. Ibid.

10. Mondeville, Law and Medical Negligence, Yale University Press, 1993, pp145, 153

11. Donoghue V Stevensen, 1923, AC 562 per Lord Mc Milliam

12. (2014) ISCC 384

13. AIR 1989, SC 1570

14. 2002 ACJ 954 (Mad. HC)

15. 2005 CPJ 35 (NC) 